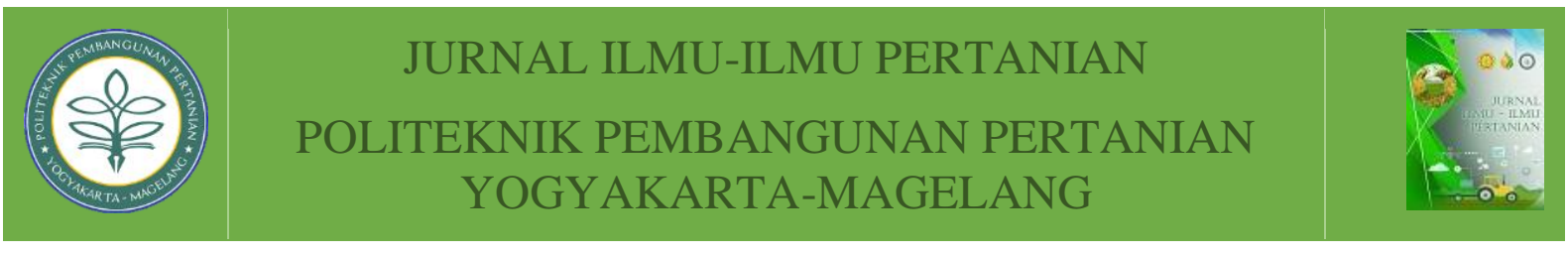

\title{
RETENSI AIR DAN DERAJAT KEJENUHAN TANAH GAMBUT DARI KAWASAN DAS SABANGAU
}

\author{
Akhmat Sajarwan ${ }^{1}$ \\ ${ }^{1}$ Fakultas Pertanian Universitas Palangkaraya, Palangkaraya, 73111 \\ : February $22^{\text {nd }}, 2021$ \\ : $\quad$ March $18^{\text {th }}, 2021$ \\ : June $17^{\text {th }}, 2021$ \\ : Authors retain copyright and grant the journal right of first \\ publication with This work is licensed under a Creative Commons \\ Attribution-Non Commercial 4.0 International License.
}

Received

Accepted

Published

Copyright Notice

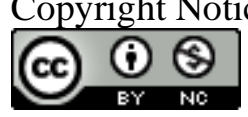

ABSTRAK: Air berperan penting dalam proses pembentukan, pengolahan, manajemen pemanfaatan, dan pelestarian tanah gambut. Tujuan penelitian ini adalah untuk mendapatkan karakteristik retensi air dan derajat kejenuhan tanah gambut. Penelitian dilaksanakan di Laboratorium Alam Hutan Gambut, Kalimantan Tengah, tahun 2007 sampai dengan tahun 2014. Contoh gambut diambil dari tiga kategori ketebalan gambut, yaitu Gambut Dangkal (SP), Gambut Sedang (MP) dan Gambut Dalam (DP), dari lapisan permukaan (0-50 cm atau L-1) dan lapisan sub permukaan (50-100 cm atau L-2). Kadar lengas volumetrik $\left(\theta_{\mathrm{w}}\right)$ L-1 selalu lebih rendah dari $L-2$, kecuali untuk $D P$, dimana kadar lengas pada aras $p F 1 ; p F 2$ dan $p F$ 2,54 pada L-1 lebih tinggi dari L-2. Kadar lengas DP, L-1 masing-masing senilai 29,36\%, $17,59 \%$ dan 13,37\% untuk aras $p F 1, p F 2$, dan $p F 2,54$, lebih rendah dari $L-2$, senilai $36,77 \%$, $18,90 \%$ dan $14,51 \%$ pada nilai aras pF yang sama. Nilai rata-rata total pori pada L-1 kategori SP, MP dan DP berturut-turut adalah 84,67\%, 86,40\% dan 86,98\%. Pada L-2, nilai rata-rata total pori kategori SP, MP dan DP berturut-turut adalah 83,53\%, 84,56\%, dan 86,93\%. Nilai derajat kejenuhan $(S)$ semua aras pF pada L-1 kategori MP cenderung lebih tinggi dari SP dan DP, kecuali $p F$ 4,20; dimana nilai $S$ untuk SP $(22,35 \%)$ lebih tinggi dari MP (10,63\%, ) dan DP (7,53\%). Selanjutnya, untuk L-2, nilai S untuk SP cenderung lebih tinggi dari MP dan DP, kecuali $p F$ 0, dimana MP mempunyai nilai $S$ yang lebih tinggi dari SP dan $D P$.

Kata Kunci : Kadar Lengas, Total Pori, Derajat Kejenuhan.

ABSTRACT: Water is an essential factor in forming, cultivation, utilization management, and sustainability of peat soil. This study aimed to obtain the characteristics of water retention and saturation degree of peat soil. The study was conducted in the Natural Laboratory of Peat Forest, Central Kalimantan. Peat sampling was taken from three-peat thickness categories, i.e. shallow (SP), medium (MP) and deep peat (DP), at a depth of 0-50 cm (surface layer) and 50 $-100 \mathrm{~cm}$ (subsurface layer). The volumetric moisture content $\left(\theta_{w}\right)$ at the surface layer is always lower than the subsurface layer, except from DP categories, where for the level of $p F 1, p F 2$ 
and $p F$ 2,54. The moisture contents for DP, at the surface layer were $29.36 \%, 17.59 \%$, and $13.37 \%$, respectively. The levels of $p F 1, p F 2$ and $p F 2,54$ were lower than the subsurface layer, which each have $36.77 \%, 18.90 \%$ and $14.51 \%$, respectively. The average value of the total pore in the surface layer was $84.67 \%$; $86.40 \%$; and $86.98 \%$ for SP, MP and DP categories, respectively. For subsurface layers, that was $83.53 \%$; $84.56 \%$; and $86.93 \%$ for SP, $M P$ and DP categories, respectively. For all $\mathrm{pF}$ levels in the surface layer, the $S$ value for MP tends to be higher than $S P$ and DP, except for $p F 4.20$, the $S P(22.35 \%)$ is higher than MP $(10.63 \%)$ and DP (7.53\%). For the subsurface layer, the S value for SP tends to be higher than $M P$ and DP, except for $p F 0$, the MP has higher than SP and DP.

\section{Keywords : Moisture Content, Pore Total and Saturation Degree.}

\section{PENDAHULUAN}

Air merupakan salah satu faktor penting dalam proses pembentukan gambut, manajemen pemanfaatan dan pengelolaan, serta dalam pelestarian gambut itu sendiri. Pengelolaan air terpadu merupakan kunci dalam merestorasi lahan gambut tropika, dimana perbedaan penggunaan lahan serta kebutuhan air yang berbeda antara penggunaan lahan tersebut, akan memerlukan upaya penyeimbangan (Ritzema et al., 1998). Pengelolaan air secara optimal pada perbedaan penggunaan lahan sangat penting artinya untuk mencapai penggunaan lahan gambut tropika yang bijak dan baik (Wösten and Ritzema, 2001).

Sebagian besar gambut tropika terbentuk di dataran rendah, dimana vegetasi hutan hujan tumbuh dan berkembang di atas akumulasi masa dan material organik dengan ketebalan tertentu, dimana bahan tersebut telah terakumulasi dan terdeposit selama ribuan tahun, sampai mencapai ketebalan lebih dari $20 \mathrm{~cm}$ (Anderson, 1983; Radjagukguk, 1995, and Page et al., 2006). Dalam dua dekade terakhir, khususnya untuk lahan gambut di Kalimantan Tengah, beberapa kebijakan kegiatan pemanfaatan dan penggunaan lahan gambut tropika selalu berhubungan dengan aspek manajemen pemanfaatan air. Sebagai contoh, salah satu kegiatan pembukaan lahan lahan adalah membangun saluran untuk mengeluarkan air yang menggenangi kawasan kubah gambut. Kebijakan ini menimbulkan kerusakan berbagai aspek ekosistem lahan gambut, pengatusan dari areal dalam kawasan gambut melalui saluran menjadi dipercepat, sedangkan ketika musim kemarau, sebagian besar lapisan tanah gambut menjadi sangat kering.

Untuk mengetahui perilaku pengaturan air tersebut, perlu dipahami tentang kapasitas gambut menampung dan/ atau menahan air (water holding capacity). Hal tersebut merupakan gambaran karakteristik air pada lahan dalam skala makro, bergantung dan berkaitan dengan kapasitas material tanah gambut (matrik gambut) untuk menahan (suction) air. Kadar air (lengas) yang dapat ditahan oleh matrik gambut bervariasi pada menurut taraf tekanan yang terdapat pada bahan matrik gambut, ini dapat dijelaskan dengan nilai kapasitas isapan (suction) yang diberlakukan, dan salah satu cara menetapkannya adalah dengan mengukur kadar lengas gambut pada beberapa nilai $\mathrm{pF}$ (tekanan lengas tanah). Pekerjaan perpindahan air dianggap sebagai suatu daya (force) yang mampu menggerakan air dalam tanah, dengan kata lain merupakan tenaga atau daya yang menjadi penyebab bergeraknya air dalam tanah, daya ini umumnya disebut sebagai air potensial $(\psi)$, yang dapat dijelaskan dengan nilai lengas pada kurva $\mathrm{pF}$. Kapasitas matrik gambut untuk menahan dan menampung air sangat tergantung kepada beberapa sifat fisiknya, terutama yang berhubungan dengan porositasnya. Pergerakan air dan kadar lengas tanah dapat dianggap sebagai fungsi gravimetri dan isotermal, yang dipengaruhi oleh beberapa faktor sifat tanah, seperti struktur, porositas dan sifat fisik lainnya (Weiss et al., 1998 and Walczak et al., 2002). 
Di areal lahan gambut yang belum dikelola, pergerakan air berperan penting dalam pelestarian fungsi alaminya sebagai komponen ekosistem. Oleh karena itu, pemahaman terhadap karakteristik retensi air tanah gambut menjadi hal yang penting, sehingga dapat dilakukan pengelolaan yang lebih baik di masa yang akan datang. Pengelolaan air berdasarkan pemahaman kondisi hidrologi lahan gambut dianggap sebagai prasyarat pengelolaan ekosistem lahan gambut yang baik dan bijak (Muhammad and Rieley, 2002; Rieley and Page, 2005). Berdasarkan alasan tersebut, dilakukan penelitian tentang retensi air dan derajat kejenuhan tanah gambut dari kawasan Daerah Aliran Sungai (DAS) Sabangau, Kalimantan Tengah. Penelitian ini bertujuan untuk mendapatkan karakteristik retensi air dan derajat kejenuhan tanah gambut.

\section{METODE \\ Bahan dan Peralatan}

Penelitian dilakukan dalam area Laboratorium Alam Hutan Gambut (LAHG) yang berlokasi di DAS Sabangau, $20 \mathrm{~km}$ sebelah barat Kota Palangka Raya. Areal ini merupakan kawasan hutan sekunder belum terbuka, dengan tingkat dekomposisi gambutnya termasuk kategori fibrik. Contoh gambut diambil dari 13 titik lokasi, dari 3 (tiga) kategori wilayah ketebalan gambut, yaitu Gambut Dangkal $(\mathrm{SP}=<100 \mathrm{~cm})$ sebanyak 1 lokasi; Gambut Sedang $(\mathrm{MP}=100-200 \mathrm{~cm})$ sebanyak 2 lokasi; dan Gambut Dalam (DP = > $200 \mathrm{~m}$ ) sebanyak 10 lokasi. Pada setiap titik sampling, diambil contoh gambut utuh menggunakan ring sampel berukuran diameter 5,1/5,0 $\mathrm{cm}$ dan tinggi $5,1 \mathrm{~cm}$, dan contoh gambut terusik diambil menggunakan bor gambut Eijkelkamp Peat Sampler. Kedua jenis contoh gambut tersebut diambil dari kedalaman 0-50 cm dan 50-100 cm, dan diberi kode SP L-1 (Gambut Dangkal 0-50 cm); SP L-2 (Gambut Dangkal 50-100 cm); MP L-1 (Gambut Sedang 0-50 cm); MP L-2 (Gambut Sedang 50-100 cm); dan DP L-1 (Gambut Dalam 0-50 cm); DP L-2 (Gambut Dalam 50-100 cm).
Penetapan nilai retensi air di laboratorium berdasarkan metode yang diinisiasi oleh Richards and Fireman (1943), dan Richards (1947). Retensi air diukur pada nilai tekanan 0.01 atm $(\mathrm{pF} 1.0)$; 0.1 atm (pF 2.0); 0.33 atm (pF 2.54); dan 15 $\operatorname{atm}(\mathrm{pF} 4.2)$.

Peralatan pada penelitian ini meliputi kompresor otomatis, panci pressure plat, panci pressure membrane, batang /tangkai, pisau, timbangan analitik, serta kelengkapan survey lainnya.

Besarnya tekanan yang diberikan ke setiap panci pressure plate, disesuaikan dengan nilai $\mathrm{pF}$ yang sudah ditetapkan sebelumnya, yaitu: (i) $\mathrm{pF} 1.0$ dengan tekanan sebesar 0.01 atm, atau setara dengan $10 \mathrm{~cm}$ tinggi kolom air bergantung; (ii) $\mathrm{pF} 2.0$ dengan tekanan sebesar $0.1 \mathrm{~atm}$, atau setara dengan $100 \mathrm{~cm}$ tinggi kolom air bergantung; (iii) $\mathrm{pF} 2.54$ dengan tekanan sebesar $1 / 3 \mathrm{~atm}$, atau setara dengan $350 \mathrm{~cm}$ tinggi kolom air bergantung; dan (iv) pF 4.2 dengan tekanan sebesar $15 \mathrm{~atm}$, atau setara dengan $15000 \mathrm{~cm}$ tinggi kolom air bergantung.

Contoh gambut disiapkan dalam kondisi jenuh yang dianggap setara dengan lengas pada nilai tekanan $0 \mathrm{~atm}(\mathrm{pF}=0)$. Parameter berat volume diukur secara gravimetri untuk contoh utuh; sebelum (berat volume basah $\left.\left(\rho_{\mathrm{b}(\text { wet })}\right)\right)$ dan setelah dioven selama 24 jam pada suhu $105{ }^{\circ} \mathrm{C}$ (berat volume kering $\left.\left(\rho_{\mathrm{b}(\mathrm{dry})}\right)\right)$, (Black and Hartge, 1986). Berat jenis diukur dengan metode piknometer (Redding, et al., 2005 and Heiskanen, 1992), dan porositas dihitung berdasarkan nilai berat volume dan berat jenis (Hillel, 1982).

\section{Prosedur analisis retensi air gambut}

Contoh gambut yang dianalisis adalah contoh gambut utuh (undisturbed) yang masih berada dalam ring. Contoh gambut yang ada dalam ring di dorong di salah satu ujung dengan tangkai pendorong (stick), kemudian bagian ujung lain yang keluar, dipotong dengan ketebalan $1 \mathrm{~cm}$ dari bagian ujungnya, kemudian dipisahkan menjadi 4 (empat) bagian yang sama. Setiap contoh gambut diletakan di atas piringan keramik yang sudah disediakan untuk pengukuran lengas pada masing-masing nilai $\mathrm{pF}$, yaitu $\mathrm{pF} 1,0 ; \mathrm{pF} 2,0 ; \mathrm{pF}$ 2,54, kecuali untuk 
penetapan lengas pada $\mathrm{pF}$ 4,2 yang mana contoh gambutnya kering-anginkan dan diayak dengan ayakan $2 \mathrm{~mm}$, baru kemudian diletakan di atas piringan keramik. Contoh gambut yang berada di atas piringan keramik dijenuhkan selama 48 jam, dan masing-masing contoh gambut dimasukan ke panci pressure plate $(\mathrm{pF} 1,0$; $\mathrm{pF} 2,0$; dan $\mathrm{pF} 2,54)$, dan satu contoh gambut untuk pengukuran dengan $\mathrm{pF} 4,2$ menggunakan panci pressure membrane. Selanjutnya panci ditutup secara kuat dan rapat, dan hidupkan kompresor untuk memberikan tekanan sesuai nilai $\mathrm{pF}$ yang telah ditetapkan. Setelah 48 jam dalam panci, contoh gambut dikeluarkan untuk selanjutnya ditetapkan kadar air (lengas) secara gravimetri. Penetapan kurva retensi air menggunakan metode van Genuchten (1980), dengan rincian sebagai berikut :

\section{- Nilai retensi air terukur}

Nilai kadar lengas dari hasil pengukuran di laboratorium merupakan kadar lengas gravimetri, dan dihitung dengan menggunakan persamaan (1) kemudian dikonversi menjadi kadar lengas volumetric $\left(\mathrm{cm} . \mathrm{cm}^{-3}\right)$, dan dinamakan sebagai kadar lengas volumetrik terukur (Wiess, et al., 1998).

$$
\theta_{v}=\theta_{m} \times \frac{\rho_{b}}{\rho_{w}}
$$

Dimana:

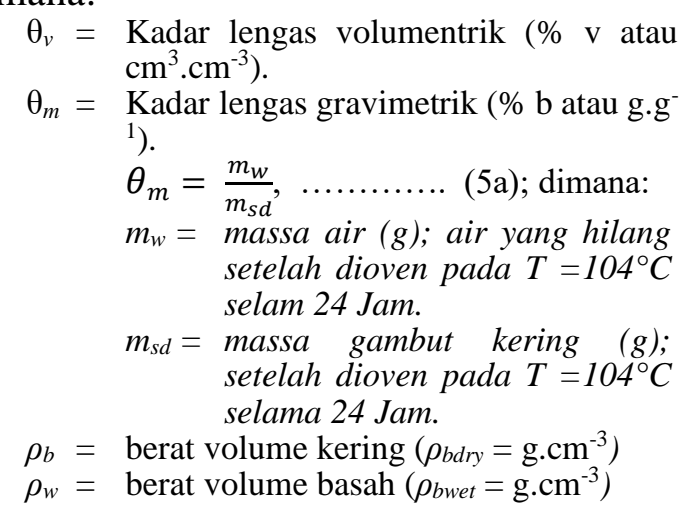

\section{- Nilai retensi air terhitung}

Nilai Terhitung kadar lengas ditetapkan dengan menggunakan persamaan van Genuchten (persamaan 2) sebagai berikut:
Dimana:
$v=$ Kadar lengas volumetrik
$\theta_{\mathrm{s}}{ }^{v}=$ kadar lengas jenuh
$\theta_{\mathrm{r}}=$ kadar lengas residual
$\psi=$ Matrik potensial $(\cong \mathrm{h}=\mathrm{cm}$ kolom air bergantung)
$\alpha, n, m=$ empirical parameters by van Genuchten

Nilai beberapa parameter van Genuchten, termasuk parameter empiriknya, ditentukan menggunakan Program SWRC Fit (http://purl.org/net/swrc) (Seki, 2007). Setelah diperoleh nilai beberapa parameter van Genuchten tersebut, selanjutnya nilai kadar lengas volumetrik dihitung dengan persamaan 2 pada lembar kerja excel menggunakan program excel solver function.

\section{- Nilai retensi air terduga}

Kadar lengas nilai terhitung ditampilkan dalam bentuk grafik, garis regresi, dan dipilih nilai $\mathrm{R}$ optimal (mendekati 1), dan diambil persamaan regresinya untuk mendapatkan nilai kadar lengas dugaan pada kisaran nilai $\mathrm{pF}$ yang lebih besar (mulai dari $\mathrm{pF} 0-\mathrm{pF}>4,25$ ).

\section{Penetapan Berat Volume $\left(\rho_{b}\right)$ dan Berat Partikel $\left(\rho_{s}\right)$}

Berat volume ditetapkan dengan metode gravimetri, terdiri dari 2 kondisi contoh gambut, yaitu dalam kondisi jenuh air, disimbolkan sebagai $\rho_{\mathrm{b} \text { (wet) dan dalam }}$ kondisi kering (setelah dioven) dan disimbolkan $\rho_{b(d r y)}$, dengan satuan g. $\mathrm{cm}^{-3}$.

$$
\begin{aligned}
& b(w e t)=\frac{W}{V} \\
& \text { dimana: } \\
& \rho_{\mathrm{b} \text { (wet) }}=\text { berat volum basah atau jenuh }\left(\mathrm{g} . \mathrm{cm}^{-}\right. \\
& 3 \text { ). } \\
& \mathrm{W}=\text { Berat basah contoh gambut sebelum } \\
& \text { di oven }(\mathrm{g}) \text {. } \\
& \mathrm{V}=\text { volume contoh gambut, dianggap } \\
& \text { sama dengan volume ring }\left(\mathrm{cm}^{3}\right) \text {. } \\
& b(d r y)=\frac{W}{V} \\
& \text { dimana: } \\
& \rho_{\mathrm{b} \text { (dry) }}=\text { berat volume kering }\left(\mathrm{g} \cdot \mathrm{cm}^{3}\right) \text {. } \\
& \mathrm{W}=\text { berat contoh gambut kering setelah }
\end{aligned}
$$


Berat partikel $\left(\rho_{s}\right)$ diukur dengan piknometer liquid, dimana piknometer diisi dengan cairan dan air pengangas (Heiskanen, 1992 and Redding et al., 2005), dan dihitung dengan persamaan berikut:

$$
s=\frac{100 x(B-A)}{(100+) x\left(V_{w 2}-V_{w 1}-V_{w 3}\right)}
$$

dimana:

$$
\begin{aligned}
& \rho_{\mathrm{s}}= \text { Berat Partikel }\left(\mathrm{g} \cdot \mathrm{cm}^{-3}\right) \\
& \mathrm{B}=\text { berat piknometer yang berisi contoh } \\
& \text { gambut lolos ayakan } 2 \mathrm{~mm}(\mathrm{~g}) \\
& \mathrm{A}=\text { Berat piknometer }(\mathrm{g}) \\
& \theta \quad=\text { Kadar lengas contoh gambut }(\%)
\end{aligned}
$$

$$
V_{w 1}=\frac{C-B}{w 1}
$$

$\mathrm{V}_{\mathrm{w} 1}=$ berat volume spesifik air $\left(\mathrm{g} \cdot \mathrm{cm}^{3}\right)$ pada suhu piknometer setelah diisi dengan air dan contoh gambut $\left(\mathrm{cm}^{3}\right)$.

$\mathrm{C}=$ berat piknometer yang berisi contoh gambut dan air $(\mathrm{g})$

$\mathrm{B}=$ berat piknometer mengandung contoh gambut (g)

$\rho_{\mathrm{w} 1}=$ Berat volume specific air pada suhu piknometer setelah diisi air $\left(\right.$ g.cm $\left.{ }^{-3}\right)$.

$$
V_{w 2}=\frac{D-A}{w 2}
$$

dimana:

$\mathrm{V}_{\mathrm{w} 2}=$ berat volume spesifik air $\left(\mathrm{g} \cdot \mathrm{cm}^{-3}\right)$ pada suhu piknometer setelah diisi hanya dengan air.

$\mathrm{D}=$ berat piknometer setelah diisi hanya dengan air $(\mathrm{g})$

$\mathrm{A}=$ berat piknometer $(\mathrm{g})$

$\rho_{\mathrm{w} 2}=$ Berat volume spesifik air pada suhu piknometer setelah diisi hanya air (g.cm $\left.\mathrm{cm}^{-3}\right)$.

$$
\begin{aligned}
& V_{w 3}=\frac{(B-A}{(100+) x_{w 3}} \\
& \text { dimana: }
\end{aligned}
$$

$\mathrm{V}_{\mathrm{w} 3}=$ berat volume spesifik air $\left(\mathrm{g} \cdot \mathrm{cm}^{-3}\right)$ pada suhu $60^{\circ} \mathrm{C}$.

$\mathrm{B}=$ berat piknometer mengandung contoh gambut (g)
$\mathrm{A}=$ berat piknometer $(\mathrm{g})$
$\theta=$ kadar lengas contoh gambut $(\%)$
$\rho_{\mathrm{w} 3}=$ berat volume spesifik air pada suhu $60^{\circ} \mathrm{C}\left(\mathrm{g} \cdot \mathrm{cm}^{-3}\right)$.

\section{Porositas}

Nilai porositas ditentukan sebagai total pori yang dihitung dari persamaan 3a dan 3 b (Ninmo, 2004) :

$\varphi=\left(1-\left(\rho_{\mathrm{b}(\mathrm{wet})} / \rho_{\mathrm{s}}\right)\right) \times 100 \%$

dimana:

$$
\begin{aligned}
& \varphi=\text { total pori }(\%) \\
& \rho_{\mathrm{b}(\text { wet })}=\text { berat volume basah dalam satuan g. } \mathrm{cm}^{-3} \\
& \text { (lihat persamaan 3a); } \\
& \rho_{\mathrm{s}} \quad=\text { berat partikel dalam satuan } \mathrm{g} \cdot \mathrm{cm}^{-3} \\
& \text { (lihat persamaan 4) }
\end{aligned}
$$

\section{Derajat kejenuhan pori}

Derajat kejenuhan menggambarkan ruang pori tanah yang dapat terisi air, dinamakan retensi air, dihitung dengan rumus Walker et al. (1931):

$$
\begin{aligned}
& S=(\theta / \eta) 100 \\
& \text { dimana: } \\
& S=\text { derajat kejenuhan }(\% \mathrm{v}) \\
& \theta=\text { Lengas volumetrik }(\% \mathrm{v}) \text { pada setiap } \\
& \text { nilai } \mathrm{pF} \\
& \eta=\text { total pori }(\%)
\end{aligned}
$$

\begin{tabular}{|c|c|c|c|c|c|c|c|c|c|c|c|c|}
\hline \multirow{3}{*}{$\mathrm{pF}$ level } & \multicolumn{4}{|c|}{ SP } & \multicolumn{4}{|c|}{ MP } & \multicolumn{4}{|c|}{ DP } \\
\hline & \multicolumn{2}{|c|}{$0-50 \mathrm{~cm}$} & \multicolumn{2}{|c|}{$50-100 \mathrm{~cm}$} & \multicolumn{2}{|c|}{$0-50 \mathrm{~cm}$} & \multicolumn{2}{|c|}{$50-100 \mathrm{~cm}$} & \multicolumn{2}{|c|}{$0-50 \mathrm{~cm}$} & \multicolumn{2}{|c|}{$50-100 \mathrm{~cm}$} \\
\hline & $\mathrm{v}$ & $\%$ & $\mathrm{v}$ & $\%$ & $\mathrm{v}$ & $\%$ & $\mathrm{v}$ & $\%$ & $\mathrm{v}$ & $\%$ & $\mathrm{v}$ & $\%$ \\
\hline 0 & 0,798 & 79,83 & 0,816 & 81,62 & 0,857 & 85,68 & 0,827 & 82,73 & 0,823 & 82,26 & 0,817 & 81,72 \\
\hline 1 & 0,789 & 78,88 & 0,803 & 80,33 & 0,832 & 83,23 & 0,807 & 80,69 & 0,804 & 80,36 & 0,808 & 80,77 \\
\hline 2 & 0,253 & 25,32 & 0,309 & 30,86 & 0,346 & 34,55 & 0,276 & 27,64 & 0,326 & 32,59 & 0,299 & 29,89 \\
\hline 2.54 & 0,207 & 20,72 & 0,269 & 26,89 & 0,325 & 32,45 & 0,256 & 25,64 & 0,294 & 29,37 & 0,275 & 27,51 \\
\hline 4.2 & 0,189 & 18,92 & 0,224 & 22,43 & 0,092 & 9,18 & 0,082 & 8,23 & 0,066 & 6,55 & 0,061 & 6,14 \\
\hline
\end{tabular}

\section{HASIL DAN PEMBAHASAN Retensi Air}

Nilai kadar lengas volumetrik (\% v/v) disajikan dalam Tabel 1. Hasil pengukuran menunjukan bahwa kadar lengas volumetrik $\left(\theta_{\mathrm{w}}\right)$ di lapisan permukaan (0-50 $\mathrm{cm})$ selalu lebih rendah dibandingkan dengan kadar lengas pada lapisan di bawahnya (sub permukaan $=50-100 \mathrm{~cm}$ ), kecuali untuk kategori DP, dimana untuk aras $\mathrm{pF} 1, \mathrm{pF} 2$ dan $\mathrm{pF} 2,54$, nilai $\theta_{\mathrm{w}}$ pada lapisan permukaan lebih tinggi dari lapisan sub permukaan.

Kejadian demikian cenderung bersifat hidrologis, dimana pergerakan air di lapisan permukaan lebih dinamis dibandingkan dengan lapisan sub permukaan (Kutilek and Novak, 1998).

Tabel 1. Nilai terukur kadar air $\left(\theta_{\mathrm{v}}\right.$ dalam $\left.\% \mathrm{v}\right)$ 
Tabel 2. Nilai parameter van Genuchten (empirical parameter menggunakan SWRC program versi 3)

\begin{tabular}{cccccc}
\hline Kurva & \multicolumn{5}{c}{ Nilai parameter van Genuchten } \\
\cline { 2 - 6 } (contoh) & $\theta_{\mathrm{r}}$ & $\alpha$ & $n$ & $\theta_{\mathrm{s}}$ & $m$ \\
\hline 1 (SP L-1) & 0.195 & 0.0312 & 3.0282 & 0.799 & 0.6698 \\
2 (SP L-2) & 0.240 & 0.0346 & 2.6417 & 0.820 & 0.6215 \\
3 (MP L-1) & 0.092 & 0.0529 & 1.5356 & 0.879 & 0.3488 \\
4 (MP L-1) & 0.110 & 0.0452 & 1.8137 & 0.847 & 0.4486 \\
5 (DP L-1) & 0.065 & 0.0504 & 1.5392 & 0.846 & 0.3503 \\
6 (DP L-1) & 0.075 & 0.0467 & 1.6346 & 0.842 & 0.3882 \\
\hline
\end{tabular}

Hasil perhitungan nilai parameter empiris van genuchten ditunjukkan pada Tabel 2. Berdasarkan data yang diperoleh, dilakukan perhitungan nilai kadar lengas volumetrik $(\theta)$ dengan memasukan parameter van Genuchten pada persamaan (2). Nilai hasil perhitungan kadar lengas sebelum dan sesudah excel solved function disajikan dalam Tabel 3. Sedangkan kurva fitting retensi air berdasarkan hasil estimasi pada nilai $\mathrm{pF}$ yang lebar disajikan pada Gambar 1.

Gambar 1 menunjukkan bahwa perubahan kadar lengas volumetrik cenderung mengikuti pola yang sama untuk semua kategori contoh gambut, tetapi kategori SP mempunyai pola yang lebih jelas dan tegas dibandingkan dengan MP dan DP. Untuk contoh gambut SP, nilai estimasi kadar lengas volumetrik hampir mendekati nilai terukur, sedangkan untuk contoh gambut MP dan DP, nisbi jauh (weak proximity) dengan nilai kadar lengas terukur. Kategori gambut dangkal (SP) dapat dianggap mewakili tanah gambut dengan tingkat kematangan hemik, yang diduga lebih mudah dipenetrasi oleh material mineral (Widjaya-Adhi, 1992). Sedangkan, untuk kategori MP dan DP, yang mempunyai tingkat dekomposisi yang lebih mentah, lebih banyak mengandung serat /fibrik serta banyak tersusun oleh fraksi berukuran kasar dibandingkan dengan contoh gambut kategori SP.

Tabel 3. Nilai kadar lengas $(\theta)$ terhitung

\begin{tabular}{|c|c|c|c|c|c|c|}
\hline \multirow{2}{*}{\multicolumn{2}{|c|}{ Kurva }} & \multicolumn{5}{|c|}{ Nilai pF } \\
\hline & & 0 & 1 & 2 & 2,54 & 4,2 \\
\hline \multirow{2}{*}{1} & B & 79,85 & 74,70 & 24,96 & 20,08 & 19,50 \\
\hline & $\mathrm{S}$ & 79,90 & 78,78 & 25,38 & 19,93 & 19,65 \\
\hline \multirow{2}{*}{2} & B & 81,77 & 73,36 & 30,69 & 25,12 & 24,00 \\
\hline & $\mathrm{S}$ & 81,99 & 80,04 & 31,13 & 24,80 & 24,27 \\
\hline \multirow{2}{*}{3} & B & 74,40 & 55,20 & 32,07 & 23,45 & 11,28 \\
\hline & $\mathrm{S}$ & 86,90 & 78,24 & 41,40 & 24,30 & 12,45 \\
\hline \multirow{2}{*}{4} & B & 79,21 & 59,36 & 27,70 & 18,59 & 11,35 \\
\hline & S & 84,44 & 77,97 & 31,21 & 17,56 & 13,41 \\
\hline \multirow{2}{*}{5} & B & 71,60 & 52,68 & 29,53 & 20,83 & 8,57 \\
\hline & $\mathrm{S}$ & 83,65 & 75,37 & 39,11 & 21,77 & 9,56 \\
\hline \multirow{2}{*}{6} & B & 74,60 & 54,94 & 28,46 & 19,26 & 8,64 \\
\hline & S & 83,60 & 76,03 & 35,80 & 19,02 & 10,27 \\
\hline
\end{tabular}

Keterangan: $\mathrm{B}=$ sebelum excel solved function; dan $\mathrm{S}=$ sesudah excel solved function

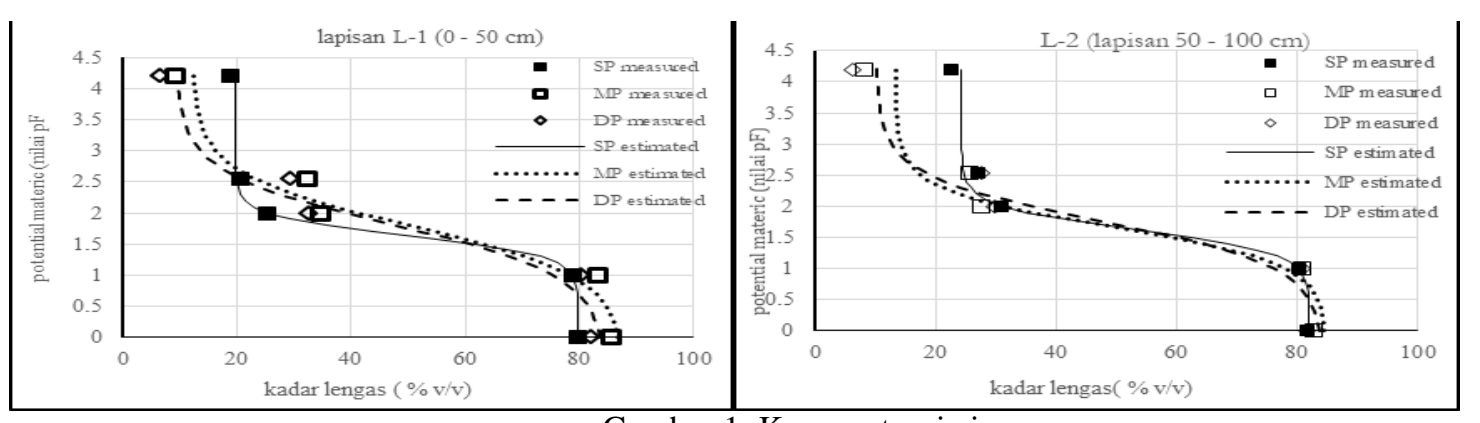

Gambar 1. Kurva retensi air 


\begin{abstract}
Kadar lengas volumetrik cenderung menurun ketika potensial air $(\psi)$ mengalami peningkatan. Perubahan besar terjadi antara $\mathrm{pF} 1 \mathrm{ke} \mathrm{pF} 2$, dan antara $\mathrm{pF} 2,54 \mathrm{ke} \mathrm{pF} 4,2$, sebaliknya hampir tidak terjadi perubahan kadar lengas volumetrik antar $\mathrm{pF} 0 \mathrm{ke} \mathrm{pF} 1$ dan antara $\mathrm{pF} 2 \mathrm{ke} \mathrm{pF} 2,54$. Kondisi ini terjadi diduga berhubungan dengan distribusi ukuran pori dalam matrik gambut tersebut. Pola yang terjadi ini sama antara lapisan permukaan $(0-50 \mathrm{~cm})$ dengan lapisan sub permukaan $(50-100 \mathrm{~cm})$. Secara umum, penampakan kurva retensi air yang diperoleh penelitian ini serupa dengan banyak hasil penelitian lainnya (Walczak et al., 2002; Campos et al., 2011; Indahyani et al., 2017 dan Madi et al., 2018).

Berdasarkan beberapa studi tentang karakateristik gambut tropika di kawasan DAS Sabangau, material mineral yang terdapat di lapisan dasar umumnya berbentuk mineral liat dengan ukuran fraksi $<2 \mu \mathrm{m}$ atau dalam bentuk bahan gambut dengan fraksi amorfik, dengan variasi masa $0,04-0,11$ g.cm ${ }^{-3}$ (Konenen et al., 2015) dan larutannya mengisi ruang pori matrik gambut. Keberadaan fraksi liat dalam matrik gambut menentukan struktur ruang pori gambut, dimana terdapat banyak fraksi berukuran halus $(<2 \mu \mathrm{m})$ termasuk mineral liat, dan ruang porinya didominasi oleh porimikro.
\end{abstract}

\section{Porositas dan kadar lengas volumetrik}

Data terkait parameter porositas disajikan pada Tabel 4. Tabel tersebut ilustrasi tentang karakteristik porositas tanah gambut, yang hanya berupa data dalam skala laboratorium, yang tidak dapat menjelaskan secara pasti dan akurat kondisi aktual di lapangan. Akan tetapi, nilai data yang diperoleh tersebut berada kisaran nilai yang normal, sebagaimana secara umum banyak ditemukan oleh penelitian lainnya. Nilai pori total $(\varphi)$ berkisar dari 0,84 $(83,3 \%)$ sampai dengan $0,87(86,98 \%)$ dan nilai porositas $(\eta)$ berkisar dari 0,83 (83,45\%) sampai dengan 0,87 (86,90\%). Menurut Radforh et al., (1977) dalam Letts et al., (2000), nilai rerata porositas gambut berkisar antara 0,81 sampai 0,95 , nilai ini lebih besar untuk gambut fibrik dibandingkan gambut saprik. Untuk kategori DP, nilai porositas lebih besar dibandingkan dengan kategori SP dan MP (Tabel 6). Tingkat kematangan gambut dalam studi ini adalah fibrik, yang ditetapkan berdasarkan nilai berat volumenya. Perbedaan nilai porositas antara lapisan permukaan dengan lapisan sub permukaan adalah tidak nyata, yaitu dengan nilai $<1$ atau $2 \%$.

Hasil lain menunjukan bahwa volume fraksi padatan tanah senilai $<20 \%$, yaitu berkisar antara 13,11\% - 16,56\%. Fakta menjelaskan bahwa kurang $1 / 3$ bagian matrik gambut berbentuk bahan padatan. Untuk gambut fibrik, material atau bahan organik penyusunnya sebagian besar mempunyai ukuran fraksi yang besar (kasar), sehingga susunan dan struktur matriksnya bersifat porus dan mudah terganggu. Salah satu parameter yang berhubungan dengan perilaku porositas gambut (yang disajikan dalam Tabel 4) adalah nilai pori $(\mathrm{e}=$ pore value $)$, yaitu senilai 5,04 dan 6,63. Nilai pori (e) yang diperoleh ini lebih rendah dibandingkan dengan nilai yang diperoleh oleh Johari et al., (2016) untuk gambut dari Parit Nipah Darat.

Tabel 4. Beberapa data terkait parameter porositas

\begin{tabular}{|c|c|c|c|c|c|c|}
\hline \multirow{3}{*}{ Parameter } & \multicolumn{6}{|c|}{ Kode contoh gambut } \\
\hline & \multicolumn{2}{|c|}{ SP } & \multicolumn{2}{|c|}{ MP } & \multicolumn{2}{|c|}{ DP } \\
\hline & L-1 & $\mathrm{L}-2$ & L-1 & L-2 & $\mathrm{L}-1$ & L-2 \\
\hline Pori total $(\varphi=\%) \varphi=(1-(\rho b / \rho \omega)) \times 100 \%$; & 84,67 & 83,53 & 86,40 & 84,56 & 86,98 & 86,93 \\
\hline $\begin{array}{l}\text { Porositas }(\eta=\%) \eta=\left(V_{V} / \mathrm{V}\right) \times 100 \% \\
\text { (Anovitz and Cole. 2015) }\end{array}$ & 84,59 & 83,45 & 86,32 & 84,48 & 86,90 & 86,85 \\
\hline $\begin{array}{l}\text { Pori void }\left(\mathrm{V}_{\mathrm{v}}=\%\right) \mathrm{V}_{\mathrm{v}}=\left(\mathrm{V}-\mathrm{V}_{\mathrm{d}}\right) \times 100 \\
\text { or } \mathrm{V}_{\mathrm{v}}=\left(\mathrm{V}-\mathrm{V}_{\mathrm{s}}\right) \times 100\end{array}$ & 84,67 & 83,53 & 86,40 & 84,56 & 86,98 & 86,93 \\
\hline $\begin{array}{l}\text { Vol. kepadatan tanah }\left(\mathrm{V}_{\mathrm{s}}=\%\right) \text { or }\left(\mathrm{V}_{\mathrm{d}}=\%\right) \\
\mathrm{Vs}=(\mathrm{V}-\eta)\end{array}$ & 15,42 & 16,56 & 13,69 & 15,53 & 13,11 & 13,16 \\
\hline Nilai pori $(e) \mathrm{e}=\left(\mathrm{V}_{\mathrm{v}} / \mathrm{V}_{\mathrm{s}}\right)$ & 5,49 & 5,04 & 6,31 & 5,44 & 6,63 & 6,61 \\
\hline
\end{tabular}


$\underline{\text { Tabel 5. Nilai derajat kejenuhan }(\mathrm{S}) \text { dalam persen }(\%) \text { pada beberapa nilai } \mathrm{pF}}$

\begin{tabular}{ccccccc}
\hline \multirow{2}{*}{ Nilai pF } & \multicolumn{3}{c}{ SP } & \multicolumn{2}{c}{ MPde contoh gambut } \\
& \multicolumn{1}{c}{$L-1$} & $L-2$ & $L-1$ & $L-2$ & $L-1$ & $L-2$ \\
\hline 0 & 94,28 & 97,71 & 99,17 & 97,84 & 94,57 & 94,01 \\
1 & 93,16 & 96,17 & 96,33 & 95,42 & 92,39 & 92,91 \\
2 & 29,90 & 36,94 & 39,99 & 32,69 & 37,47 & 34,38 \\
2,54 & 24,47 & 32,19 & 37,56 & 30,32 & 33,77 & 31,65 \\
4,2 & 22,35 & 26,85 & 10,63 & 9,73 & 7,53 & 7,06 \\
\hline
\end{tabular}

Berdasarkan data yang disajikan dalam Tabel 5, di lapisan permukaan (L-1) untuk semua aras $\mathrm{pF}$, nilai $\mathrm{S}$ untuk MP cenderung lebih tinggi dibandingkan SP dan DP, kecuali untuk $\mathrm{pF}$ 4,2 dimana SP dengan nilai $\mathrm{S}$ sebesar 22,35\% lebih tinggi dibandingkan MP $(10,63 \%)$ dan DP (7,53\%). Selanjutnya, untuk lapisan sub permukaan (L-2), nilai $\mathrm{S}$ untuk SP cenderung lebih tinggi dibandingkan dengan MP dan DP, kecuali untuk pF 0 , dimana MP mempunyai nilai $S$ lebih tinggi dibandingkan SP dan DP. Fenomena lain terkait dengan nilai $\mathrm{S}$ telah ditemukan pada semua aras nilai $\mathrm{pF}$ pada lapisan permukaan
(L-1) untuk kategori MP dan DP, yaitu cenderung lebih tinggi dibandingkan nilai $S$ pada lapisan sub permukaan (L-2). Hal ini tidak terjadi kategori SP, dimana nilai $\mathrm{S}$ untuk lapisan sub permukaan (L-2) cenderung lebih tinggi dibandingkan dengan lapisan permukaan (L-1). Berdasarkan fakta tersebut, dapat disimpulkan bahwa derajat kejenuhan (S) cenderung menurun dengan semakin dalam lapisan gambut. Hal ini diduga berhubungan dengan pergerakan air dalam matrik gambut, dengan kondisi jenuh atau mendekati jenuh, baik pergerakan vertikal maupun horizontal.

Tabel 6. Berat volume $\left(\rho_{b}=\mathrm{g} \cdot \mathrm{cm}^{-3}\right)$, berat partikel $\left(\rho_{(s)}=\mathrm{g} \cdot \mathrm{cm}^{-3}\right)$ dan pori total $(\varphi=\%)$.

\begin{tabular}{ccccc} 
Kode contoh & $\begin{array}{c}\rho_{\mathrm{b} \text { (wet })} \\
\text { Lapisan permukaan }(\mathrm{L}-1=0-50 \mathrm{~cm})\end{array}$ & $\rho_{b(\text { dry })}$ & $\rho_{(s)}$ & \\
\hline SP-1 & 0,094 & 0,22 & 0,67 & 84,67 \\
MP-1 & 0,087 & 0,18 & 0,64 & 86,47 \\
MP-2 & 0,084 & 0,20 & 0,61 & 86,32 \\
DP-1 & 0,087 & 0,14 & 0,61 & 85,84 \\
DP-2 & 0,080 & 0,14 & 0,59 & 86,41 \\
DP-3 & 0,070 & 0,13 & 0,63 & 88,87 \\
DP-4 & 0,070 & 0,16 & 0,59 & 87,99 \\
DP-5 & 0,067 & 0,13 & 0,56 & 88,06 \\
DP-6 & 0,074 & 0,13 & 0,58 & 87,23 \\
DP-7 & 0,064 & 0,12 & 0,57 & 88,92 \\
DP-8 & 0,074 & 0,12 & 0,53 & 85,83 \\
DP-9 & 0,074 & 0,13 & 0,57 & 87,02 \\
DP-10 & 0,090 & 0,11 & 0,55 & 83,61 \\
\hline & Lapisan & sub permukaan $(\mathrm{L}-2=50-100 \mathrm{~cm})$ & \\
\hline SP-1 & 0,127 & 0,26 & 0,77 & 83,53 \\
MP-1 & 0,107 & 0,20 & 0,66 & 83,71 \\
MP-2 & 0,094 & 0,16 & 0,64 & 85,41 \\
DP-1 & 0,087 & 0,16 & 0,59 & 85,34 \\
DP-2 & 0,090 & 0,17 & 0,60 & 84,84 \\
DP-3 & 0,087 & 0,16 & 0,59 & 85,17 \\
DP-4 & 0,080 & 0,17 & 0,56 & 85,72 \\
DP-5 & 0,077 & 0,12 & 0,57 & 86,42 \\
DP-6 & 0,087 & 0,14 & 0,59 & 85,24 \\
DP-7 & 0,074 & 0,13 & 0,57 & 87,06 \\
DP-8 & 0,080 & 0,10 & 0,57 & 90,83 \\
DP-9 & 0,067 & 0,11 & 0,54 & 86,94 \\
DP-10 & 0,074 & 0,12 & 0,54 & 86,37 \\
\hline
\end{tabular}




\section{Hubungan antara berat, berat partikel dan porositas}

Parameter berat, berat partikel dan porositas diperoleh dengan prosedur sebagaimana disebutkan pada bagian sebelumnya dan dihitung dengan persamaan 3 (a dan b); (4) dan persamaan (5). Hasil perhitungan dan penetapan sebagaimana disajikan dalam Tabel 6.

Sedangkan untuk kategori DP, berat volume basah $\left(\left(\rho_{b(w e t)}\right)\right.$ berkisar $0,064-$ $0,090 \mathrm{~g} \cdot \mathrm{cm}^{-3}$ dan berat volume kering $\left(\rho_{b(d r y)}\right)$ senilai $0,11-0,16$ g.cm ${ }^{-3}$. Untuk lapisan sub permukaan, nilai berat volume basah $\left(\rho_{b(\text { wet })}\right)$ untuk kategori MP berkisar $0,094-0,107$ g.cm ${ }^{-3}$ dan berat volume kering $\left(\rho_{b(d r y))}\right)$ berkisar $0,16-0,20$ g.cm ${ }^{-3}$. Sedangkan untuk kategori DP, berat volume basah $\left(\rho_{b(w e t)}\right)$ berkisar antara 0,067 - 0,090 g.cm ${ }^{-3}$ dan berat volume kering $\left(\left(\rho_{b(\text { wet })}\right)\right.$ berkisar antara $0,10-0,17 \mathrm{~g} \cdot \mathrm{cm}^{-3}$. Berat volume kering selalu lebih tinggi dibandingkan dengan berat volume basah. Hal ini tidak saja berhubungan dengan fenomena pengaturan air dari matrik gambut yang diikuti dengan peristiwa pengerutan (shrinkage) volume gambut, tetapi juga berkaitan dengan kandungan fraksi berukuran halus dalam matrik gambut dan juga dalam pori-porinya (Boelter, 1968). Ketika bahan gambut mengalami kekeringan, volumenya mengalami penyusutan, disebabkan oleh peristiwa pengerutan atau penyusutan (shrinkage).

\section{Berat Partikel}

Berdasarkan data yang disajikan dalam Tabel 6, nilai berat partikel $\left(\rho_{\mathrm{s}}\right)$ di lapisan permukaan (L-1) dan lapisan sub permukaan (L-2) untuk kategori SP selalu lebih tinggi dibandingkan kategori MP dan DP, yaitu nilai berat partikel untuk SP 0,67 g.cm ${ }^{-3}$ dan 0,77 g.cm ${ }^{-3}$; untuk kategori MP berkisar $0,61 \mathrm{~g} . \mathrm{cm}^{-3}-0,63 \mathrm{~g} . \mathrm{cm}^{-3}$ dan untuk kategori DP berkisar 0,53 g.cm ${ }^{-3}-0,63$ g.cm ${ }^{-3}$.

Hubungan antara berat volume, berat partikel dan porositas disajikan dalam Gambar 2. Gambar 2 menunjukkan bahwa nilai pori total $(\varphi)$ untuk lapisan permukaan dan sub permukaan cenderung menurun ketika nilai berat volume dan berat partikel mengalami peningkatan, tetapi nilai koefisien korelasinya tergolong rendah,

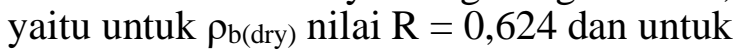
$\rho_{s}$ nilai $R=0,375$. Fakta ini seakan memberikan konfirmasi adanya hubungan yang proporsional antara berat volume dan berat partikel dengan parameter pori total, walaupun parameter berat volume kering tidak digunakan langsung dalam perhitungan nilai parameter pori total. Porositas menggambarkan ruang volume matrik gambut yang dapat diisi oleh air atau udara. Hal tersebut tergantung pada formasi struktur fraksi dalam matrik gambut. Berat volume sebagai salah satu parameter yang menggambarkan struktur massa padatan gambut dengan ruang pori di dalamnya.

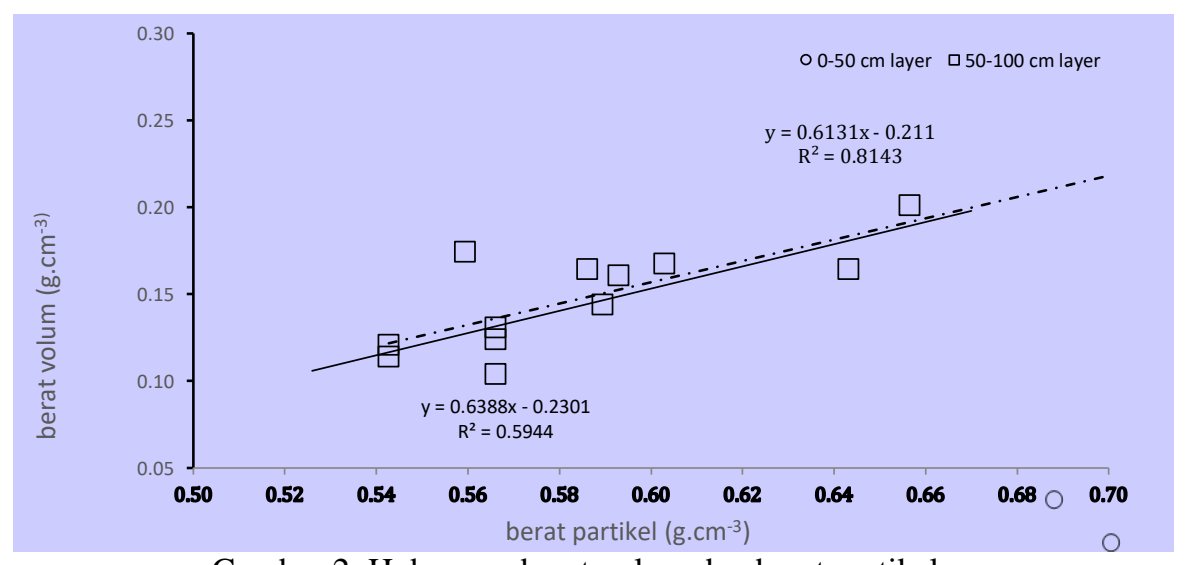

Gambar 2. Hubungan berat volum dan berat partikel

Walaupun kedua parameter tersebut menggambarkan objek yang sama, yaitu massa padatan gambut, namun perbedaan antara keduanya dianggap sama dengan volume, karena itu perbandingan antara kedua parameter tersebut berbanding lurus 
berada dalam garis yang sejajar (Gambar 2). Koefisien regresi (R) pada lapisan permukaan senilai 0,814 , lebih tinggi dibandingkan dengan lapisan sub permukaan, yaitu $\mathrm{R}=0,594$. Rendahnya nilai $\mathrm{R}$ untuk lapisan sub permukaan $(\mathrm{R}<$ 0,75) mengindikasikan bahwa peningkatan volume massa padatan tidak selalu diikuti oleh peningkatan jumlah massa padatan, dengan kata lain, bisa terjadi volume massa padatan tetap, tetapi bobot/massa padatan bertambah.

Ketidak-konsistenan tersebut barangkali berhubungan dengan dinamika fisika bahan gambut yang berada dekat dengan lapisan dasar tanah (ground mineral), terutama perilaku porositas seperti struktur dan susunan pori dalam matrik gambut. Bahan gambut yang dekat dengan lapisan mineral di bagian dasar mempunyai sifat elastis dan plastis, sehingga memungkinkannya untuk mengembang dan berkontraksi ketika basah atau kering (Boelter, 1965). Porositas secara konseptual dapat dimaknai secara parsial ke dalam 2 komponen, yaitu porositas tekstur dan porositas struktural. Komponen tekstural adalah porositas yang tersusun dari partikel acak, (sebagaimana yang ditemukan dalam penelitian ini), materialnya berbentuk granular tanpa sementasi. Dalam media granular, terdapat sekitar $0,3 \quad(30 \%)$ (Ninmo, 2004).

\section{SIMPULAN}

Karakteristik lengas volumetrik matrik gambut mempunyai pola yang sama untuk semua kategori ketebalan gambut, yaitu dangkal (SP), gambut sedang (MP) dan gambut dalam (DP). Aras kadar lengas pada SP selalu tampak lebih tinggi dibandingkan dengan MP dan DP, dan ini terjadi baik pada lapisan permukaan $(0-50 \mathrm{~cm})$ maupun pada lapisan sub permukaan $(50-100 \mathrm{~cm})$. Hal ini diduga terjadi karena adanya pengaruh kelarutan bahan mineral ke dalam larutan matrik gambut, yang didukung oleh keberadaan lapisan mineral di lapisan dasar di bawah lapisan gambut.

Untuk semua kategori ketebalan gambut dan pada lapisan pengambilan contoh gambut yang berbeda, kadar lengas volumetrik pada $\mathrm{pF} 4,2<20 \%$ volume dan pada $\mathrm{pF} 0$ maksimal senilai $86 \%$ volume. Fenomena pertama menunjukan bahwa ketika ada tenaga atau daya (potensial air) dikenakan kepada matrik gambut untuk melepaskan air setara dengan tekanan pada 15 atm, maka kurang dari $20 \%$ volume matrik gambut masih dapat terisi oleh air. Fenomena kedua menunjukan bahwa ketika terdapat tenaga atau daya dikenakan kepada matrik gambut untuk melepaskan air setara dengan tekanan sebesar 0 atm (atau mendekati 0 atm (di lapangan dalam kondisi tergenang) atau dalam keadaan jenuh, maka maksimal $86 \%$ volume gambut yang dapat terisi oleh air.

Nilai derajat kejenuhan (S) pada kategori SP untuk aras $\mathrm{pF} \geq 1(\mathrm{pF} 1-\mathrm{pF}$ 4,2) selalu lebih tinggi dibandingkan dengan kategori MP dan DP pada kedua lapisan pengambilan contoh gambut, sedangkan pada $\mathrm{pF} 0$, selalu lebih rendah dibandingkan dengan MP dan DP. Untuk semua kategori ketebalan gambut, nilai derajat kejenuhan (S) lapisan permukaan tidak berbeda secara nyata dengan lapisan sub permukaan di bawahnya.

Terdapat hubungan yang lemah antara parameter berat volume dan berat partikel dengan porositas, walaupun nilai porositas cenderung menurun ketika terjadi peningkatan nilai berat volume dan berat partikel, dengan nilai koefisien $\mathrm{R}$ yang rendah, yaitu $R=0,624$ untuk berat volume dan $\mathrm{R}=0,375$ untuk berat partikel. Kepadatan atau kerapatan matrik gambut secara kuat dikontrol oleh sifat fisiknya, termasuk struktur dan susunan porinya.

\section{PUSTAKA ACUAN}

Anderson J.A.R. (1983). The tropical peat swamps of Malesia. In: Gore AJV (ed) Ecosystems of the world: mires: swamp, bog, fen and moor. Vol. 4B. Regional studies. Elsevier, New York. pp. 181- 199.

Blake G.R. dan Hartge K.H. (1986). Bulk density. In A. Klute (ed.) Methods of soil analysis. Part 1. Physical and mineralogical methods. American Society of Agronomy/Soil Science Society of America, Madison, Wisconsin, USA. pp. 363-375.

Boelter D.H. (1965). Hydraulic 
conductivity of peats. Soil Sci. 100. pp 606-609.

Campos J.R.R., Silva A.C., Fernandes J.S.C., Ferreira M.M. dan Silva D.V. (2011). Water retention in a peatland with organic matter in different decomposition stages. R. Bras. Ci. Solo, 35. pp 1217-1227.

Heiskanen J. (1992). Comparison of three methods for determining the particle density of soil with liquid pycnometers. Commun. Soil Sci. Plant Anal. 23. pp 841-846.

Hillel D. (1982). Introduction to soil physics, 392 pages, ISBN:0123485207. Academic Press, New York.

Indahyani S., Sumawinata B. dan Darmawan. (2017). Pengukuran retensi air tanah gambut menggunakan kombinasi three phase meter dan ceramic plate. Buletin Tanah dan Lahan, 1 (1) Januari 2017: pp 109-114.

Johari N.N., Bakar I, Razali S.N.M. dan Wahab N. (2016). Fiber Effects on Compressibility of Peat. IOP Conf. Ser.: Mater. Sci. Eng. 136. 012036.

Kanzari S, Hachicha M.M. dan Bouhlila R. (2012). Laboratory Method for Estimating Water Retention Properties of Unsaturated Soil. Walailak J. Sci \& Tech 2012; 9(4): pp 361-367.

Kennedy G.W., Price J.S. (2005). A conceptual model of volume-change controls on the hydrology of cutover peats. J. Hydrol. 302. pp 13-27.

Kutilek M. dan Novak V. (1998). Exchange of water in the soil-plant-atmosphere system. Int. Agrophysics, 12. pp 2833.

Madi R., de Rooij G.H., Mielenz H. dan Mai J. (2018). Parametric soil water retention models: a critical evaluation of expressions for the full moisture range. Hydrol. Earth Syst. Sci., 22, 1193-1219.

Muhammad N.Z. and Rieley J.O. (2002). Management of tropical peatlands in Indonesia: mega reclamation project in Central Kalimantan, in: J.O. Rieley and S.E. Page (Eds.) with B. Setiadi: Peatlands for People: Natural Resource Functions and Sustainable Management, Proc. of the Inter.
Symposium on Tropical Peatland, 22-23 August 2001, Jakarta, Indonesia, BPPT and Indonesian Peat Association, pp. 155-167.

Ninmo J.R. (2004). Porosity and pores size distribution. in: Hillel, D., ed. Encyclo-pedia of Soils in the Environment: London, Elsevier, v. 3, p. 295-303.

Okruszko J. (1993). Transformation of fenpeat under the impact of drainage. Zesz. Probl. Post. Nauk Roln., 406. pp 3-74.

Page S.E., Rieley J.O. dan Wiist R. (2006). Lowland tropical peatland of Southeast Asia. In: Martini,P., Martinez-Cortizas, A., Cheswort, W. (ed) Peatlands: Evo-lution and record of environmental and climate changes. Dev. in earth surface processes series. Elsevier. pp 145 172.

Radjagukguk B. (1995). Peat soil of Indonesia: location, classification, and problems for sustainability. In: Biodiversity and Sustainability of Tropical Peatlands. Proc. of the Int. Symp. on Biodiversity, Environmental Importance of Trop. Peat and Peatlands. (eds) Rieley, J.O., and Page, S.E.; Samara Publ. UK. pp 45-54.

Rezanezhad F., Price J.S, and Craig J.R. (2012). The effects of dual porosity on transport and retardation in peat: a laboratory experiment. Can. J. Soil Sci. 92. pp 723-732.

Rezanezhad F., Price J.S., Quinton W.L., Lennartz B., Milojevic T. dan van Cappellen P. (2016). Structure of peat soil and implication for water storage, flow and solute transport: A review update for geochemists. Chemical Geology: 429. pp 75 - 84. Elsevier Publisher.

Rezanezhad F., Quinton W.L., Price. J.S., Elrick D., Elliot T. dan Heck R. (2009). Examining the effect of pore size distribution and shape on flow through unsaturated peat using computed tomography. Hydrol. Earth Syst. Sci. 13. pp 1993-2002.

Rezanezhad F, Quinton W L, Price J S, Elrick D, Elliot $\mathrm{T}$ and Shook $\mathrm{K}$ R. (2010). Influence of pore size and geometry on peat unsaturated 
hydraulic conductivity computed from 3D computed tomography image analysis. Hydrol. Process. 24. pp 2983-2994.

Richards L.A. dan Fireman L.A. (1943). Pressure plate apparatus for measuring moisture sorption and transmission by soils. Soil Sci. 56. pp 395-404.

Richards L.A. (1947). Pressure membrane apparatus, construction and use, Agric. Eng. 28. pp 451-454.

Ritzema H.P., Mutalib Mat Hassan A. dan Moens R.P. (1998). "A New Approach to Water Management of Tropical Peatlands: A Case Study from Malaysia, Irrigation and Drainage Systems, 12 (2). pp 123139.

Seki K. (2007). SWRC fit - a nonlinear fitting program with a water retention curve for soils having unimodal and bimodal pore structure. Hydrol. Earth Syst. Sci. Discuss.4:407-437. www.hydrol-earth-syst-scidiscuss.net

van Genuchten M.T. (1980). A closed-form equation for predicting the hydraulic conductivity of unsaturated soils, Soil Sci. Soc. Am. J., 44. pp.892-898.

Walczak R., Rovdan E. dan Witkowska-
Walczak B. (2002). Water retention characteristics of peat and sand mixtures. Int. Agrophysics, 16. pp 161-165.

Walker R.H, Firkine B.J. dan Brown P.E. (1931). The Measurement of the Degree of Saturation of Soils with Bases. Research Bulletin. No 139. Agronomy section soils. Agri. Experiment Station. IOWA State College of Agriculture and Mechanic Arts.

Weindorf D.C. dan Wittie R. (2003). Determining particle density in dairy manure compost. The Texas Journal of Agricultural and Natural Resource. 16. pp. 60-63.

Weiss R., Alm J., Laiho R. dan Laine J. (1998). Modeling Moisture Retention in Peat Soils. Soil Science Society of America Journal. 62. pp 305-313

Widjaya-Adhi I.P.G. (1992). Development of deep tropical peatland for parrenial crops. Proc. Int. Symp. on Trop. Peatland. Kuching Malaysia. 380384.

Wösten J.H.M. dan Ritzema H.P. (2001). "Land and Water Management Options for Peatland Development in Sarawak, Malaysia," International Peat Journal. 11. Pp 59-66.

DOI : 